\title{
Integration of Geospatial Technology and AHP knowledge Based Technique in Preparation of Susceptibility Modelling to Gully Erosion: A Study from Cratonic Part of Eastern India
}

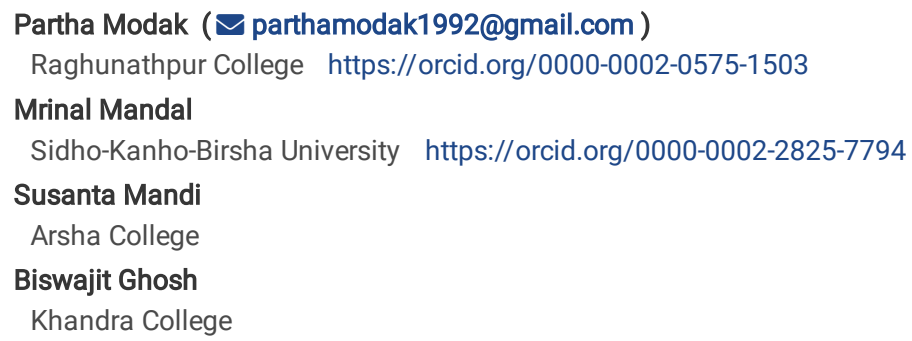

Research Article

Keywords: Gully erosion, River basin, Geospatial technology, AHP, Mapping, Accuracy assessment

Posted Date: March 2nd, 2022

DOI: https://doi.org/10.21203/rs.3.rs-1316198/v1

License: (c) (i) This work is licensed under a Creative Commons Attribution 4.0 International License. Read Full License 


\section{Abstract}

Gully erosion is conceived as one of the environmental problems resulting mainly from surface run-off and associated geo-physical factors. This erosion augments the process of land degradation. To identify the major factors responsible in this process and their assessment in preparation of gully erosion susceptibility mapping, the geospatial technology has been a huge support for earth scientists for decades. Proper analysis and assessment of satellite images employing multi-criteria decision making models facilitates the estimation of areas of soil erosion and gully formation. The present study, carried out in eastern plateau fringe of India using Remote Sensing (RS) and Geographical Information System (GIS), and Analytical Hierarchy Process (AHP) model to assess zones susceptible to gully erosion. The study reveals around $52 \%$ area of Rupai basin experiences moderate to very high gully erosion, and the model is validated performing an accuracy assessment, which is computed as $72.72 \%$. The factors are hold major responsible factors in soil erosion and gully formation are geomorphology, slope, Land Use and Land Cove (LULC), soil and Stream Power Index (SPI). Sites, such as Kutidih, Mahakudar and Kuki experience loss of soil approximately $6.09,40.96$, and 1.40 tonne respectively. The generated gully erosion susceptibility map may help in planning and management of soil and water conservation.

\section{Introduction}

Soil is considered to be one of the fundamental parameters in enhancing the regional economy (Das et al. 2020). The 21st century has witnessed rapid population growth with increasing food demand (Ghosh et al. 2021a). This situation severely impacts on soil health. The low level of soil productivity is mainly resulted from excessive use of modern technology and instruments, fertilizer and pesticides. Moreover, extensive mining, industrialization, agricultural practices, sparsely vegetated and deserted lands have direct bearing on upper most portions of soil profile and texture, and ultimately soil erosion starts (Onyando et al. 2005; Zhou et al. 2008). Gully erosion, a destructive form of soil erosion, is caused due to removal of different sediments, sands and rocks etc., from soil or earth surface by the strong surface run-off (Kirkby and Bracken 2009). In recent past, soil erosion turns out to be a global issue owing to loss of soil and agricultural lands and decreasing trend in crop production (Tilahun et al. 2014; Assefa and Hans-Rudolf 2016; Kebede et al. 2020). It was estimated that more than $60 \%$ of the world's populations depend on agriculture activities (FAO 2017); whereas in India, the figure is around $62 \%$. Interestingly, they belong to the rural areas where main option of livelihood is agriculture (Census of India 2011). The common environmental problem in semi-arid region is land degradation resulting from soil erosion (Bufalo and Nahon 1992; DeRose et al. 1998; Bennet et al. 2000; Martinez-Casasnovas et al. 2003). Several parts of India have been experiencing the issue of land degradation due to much soil erosion (Vrieling 2006). This serious problem is associated with other events like flooding, desertification, pollution of ground water and loss of soil productivity (Govers et al. 2017; Odunuga et al. 2018; Swarnkar et al. 2018). It is found that quality of land use in agricultural watershed degrades owing to soil erosion (Amiri et al. 2019). Globally, the rate of soil formation is $10-40$ times less than the soil erosion (Pimentel 2006).

Hence, the event of gully erosion is serious threat to the sustainable man-environment relation along with economic progression (El Maaoui et al. 2012; lonita et al. 2015; Ibáñez et al. 2016; Rodrigo-Comino and Cerdà 2018), and it is highly associated with poverty and food scarcity in rural agro-ecosystem (Ayele et al. 2015). The rate of sediment erodibility is attributed to lithology, soil, topography, volume and velocity of surface run-off and land use. These are the major factors of gully formation (Patton and Schumm 1975; Imeson and Kwaad 1980; Poesen et al. 2003; Martínez-Casasnovas et al. 2004; Valentin et al. 2005; Zucca et al. 2006; Gómez Gutiérrez et al. 2011; Torri et al. 2012). In the hilly and plateau region, the land erosion is found to be very common along with its associated problems, and the severity of erosion varies from place to place and influences activities of local area development (Fadul et al. 1999). The degraded landforms are much susceptible to soil erosion, and precise mapping helps to take required initiatives to reduce and manage the soil erosion (Krikby et al. 2009). Thus, it becomes imperative to identify the problems of soil erosion areas to assess the types of land development and trend of erosion for planning and measurement strategies (Daiand Lee 2002; Ayalew et al. 2004; Bijukchhen et al. 2013; Erener et al. 2016; Pham et al. 2017).

Susceptibility mapping of soil erosion is often performed to perceive the events like landslide or gully erosion. The basic goal of this technique is to demarcate the risk prone areas and to identify the influential geo-environmental factors. To understand the sensitivity of a region, the qualitative theories and statistical measurements techniques are widely employed by experts along with Geographical Information System (GIS). Worldwide Several researchers have adopted Universal Soil Loss Equation (USEL)/ Revised Universal Soil Loss Equation (RUSLE) model to estimate the terrain susceptibility on the basis of rate of soil erosion (Besler 1987; de Neergaard et al. 2008; Vijith and Dodge-Wan 2018). Several times, researchers face problems related to insufficient data on gulling and landslides; therefore, it becomes difficult to generate maps and point out the locations of landslides or gullies during field visits. In such case, various models, such as artificial neural network, multi criteria evaluation, weighting and ranking based method, were applied by different scholars to assess the degree of soil erosion risk (Dandapat et al. 2020). In some cases, these models have their own limitations to quantify the impacts of different environmental factors with soil erosion interaction owing to complex nature of soil erosion process (Kheir et al. 2006).

But model like Analytical Hierarchy Process (AHP), a popularized, efficient, simple and consistent, well defined and predictive test model using experts' opinions and statistical measurements, is generally adopted to overcome shortcomings (Ghosh et al. 2020a, 2021; Karmakar et al. 2021). Numerous scholars across the world used the AHP model to estimate the susceptibility to landslide or soil erosion in different regions, and found suitable results in predicting the vulnerability based on selected parameters (Neaupane and Piantanakulchai 2006; Yalcin 2008; Nekhay et al. 2009; Althuwaynee et al. 2012; Youssef et al. 2012; Kayastha et al. 2013; Pourghasemi et al. 2013; Rahaman and Aruchamy 2017; Arabameri et al. 2018). Therefore, it is important to have a model with more integrated approach to analyse different environmental factors more systematically in quantifying the severity of soil erosion process (Ghosh et al. 2020a, 2021). In recent times, AHP model coupled with Remote Sensing (RS) and GIS has drawn attention significantly among various scholars (Rozos et al. 2011; Li et al. 2015; Das et al. 2018, 2020). Several researchers have carried out many studies on identification of vulnerable areas to soil erosion integrating AHP model with geospatial technology (Nasiri 2013; Pradeep et al. 2014; Abbasi et al. 2017; Thomas et al. 2018).

The present study is conducted on the Rupai river basin, situated in the extended part of Chotanagpur Granite Gneiss Complex (CGGC) of Purulia district in the state of West Bengal, India. The entire basin is mainly composed of hard rock of granite gneiss, granite and biotite granite (Fig. 9). The study area receives

Page 2/19 
sufficient precipitation seasonal basis (Ghosh et al. 2020a, b, c), but surface run-off is high due to high degree of slope and low porous lithology (Ghosh $2020 a, b, 2021)$. This situation enhances the degree of soil erosion in the form of gully formation mainly in monsoon period. It is important to map the areas susceptible to soil erosion and gully formation and its spatial distribution of varying magnitude. And to do the same, this study includes AHP model with RS \& GIS to assess the event. Besides this, an attempt has also been made here to estimate the loss of soil from the studied segments.

\section{Geographical Settings of Rupai River Basin}

Rupai, an important left bank tributary of Subarnarekha river in CGGC, flows in western part of Purulia district. It originates from Jhalda-I community development block of Purulia with a length of $136.46 \mathrm{~km}$ occupying an area of $141.48 \mathrm{~km}^{2}$, and meets with Subarnarekha river at Jhalda-II community development block of Purulia. The study area lies in between $85^{\circ} 53^{\prime} \mathrm{E}$ to $86^{\circ} 02^{\prime} 30^{\prime \prime} \mathrm{E}$ and $23^{\circ} 15^{\prime} 30^{\prime \prime} \mathrm{N}$ to $23^{\circ} 23^{\prime} \mathrm{N}$ longitudes and latitudes respectively (Fig. 1). Regionally the area is a part CGGC of eastern Indian peninsular shied and belongs to the north of Singhbhum craton (Duloi 2016). The presence of china clay in the district is largely associated with Precambrian granitic rocks and meta-sediments of the CGGC. The district is characterized by undulating rolling topography with moderate to gentle slope (Ghosh 2020a, 2021; Karmakar 2021). The lithology of the district is mainly dominated by Archean granite gneiss followed by sandstone and shale of Permo-Carboniferous, Pre-Cambrian granites and quartzite, semi-consolidated sediments of Quaternary and deposition of recent alluvium sediments of recent time (Duloi 2016). Purulia experiences sub-tropical hot and dry climate (Chakrabarty 2011; Government of India 2018; Ghosh et al. 2020a), and enjoys annual rainfall and temperature ranging from 1100 to $1500 \mathrm{~mm}$ and $7^{\circ}$ to $46^{\circ} \mathrm{C}$ respectively (Government of West Bengal 2007, 2014; ). The vegetation of the study area is mainly deciduous in nature, and major forest covers are Shorea Robasta, Vachellia, Butea Monosperma, Madhuca Longifolia, Aegle Marmelos, etc., which are sparsely distributed (Mandal et al. 2018; Ghosh et al. 2020a, b). In the study area, a number of residual hills are found and soil is mainly skeletal in nature and more likely to be infertile (Ghosh et al. 2020b, c). Basically, the soil of the study of interest is lateritic nature as it belongs to Rarh Bengal (red soil area, mainly Purulia, Paschim Medinipur, Bankura, Paschim Barddhaman district of West Bengal). These areas are characterized by dense network of rills and gullies forming badland topography (Ghosh et al. 2021b)

Figure 1 is near here

\section{Materials And Methods Sources of Database}

The field study is carried out in the month of October 2021 in Rupai river basin. Collection of primary data involves measurements of gullies. Total station survey (Geomax ZT-20) is done to make long and cross profiles. Handheld Global Positioning System (GPS) of Garmin eTrex-20 is used to precisely locate the sites of investigation. A total number of eleven sites are visited after carefully observing different temporal images of the basin from Google Earth Pro software. During the field study, it is found that three sites are more susceptible to gully erosion. Hence, all the measurements are done in those sites only. To have the proper knowledge regarding soil erosion and gully formation, it is important to obtain other relevant data which only can be obtained from secondary sources. Understanding and assessment of soil erosion and gully formation requires basic information on a number of factors (Valentin et al. 2005; Conforti et al. 2011; Arabamari et al. 2018). Parameters in the process of gully erosion are not same for all regions (Arabamari et al. 2018), and needs attention in the selection of parameters emphasizing on local influential factors. In this present study, a number total number of ten factors, such as geomorphology, slope, land use and land cover (LULC), soil, Stream Power Index (SPI), curvature, lithology, elevation, drainage density and Topographical Wetness Index (TWI) have been taken into account to perform the study of Gully Erosion Susceptibility Mapping (GESM). Data required on these factors are obtained from several national and international sources, such as Digital Elevation Model (DEM) of Shuttle Radar Topography Mission (SRTM) downloaded from http:/earthexpolrer.usgs.gov (spatial resolution of 1-arc second) acquired on 23rd September 2014; Landsat-8 Operational Land Imager (OLI) satellite image downloaded from https:/earthexplorer.usgs.gov (30 m spatial resolution) obtained on 2nd April 2019; geomorphological map on a 1:250000 scale of Geological Survey of India (GSI); soil map on a 1:250000 scale of National Bureau of Soil Survey and Land Use Planning (NBSS\&LUP) of India to make individual thematic layer of all selected parameters. In order to process, analyse and prepare the different thematic maps, ArcGIS 10.3 .1 and Erdas Imagine 2014 RS and GIS software are used.

\section{Thematic Layers and Its Preparation}

While preparing the thematic layers, maps are properly geo-coded following the Universal Transverse Mercator (UTM) projection, world geodetic survey (WGS84 ) and $45 \mathrm{~N}$ zone. The delineation of Rupai drainage basin and preparation of drainage density layer is mapped from SRTM-DEM in ArcGIS software adopting hydrology tool of spatial analyst. To produce elevation, slope, curvature, SPI and TWI thematic layers, the SRTM-DEM is also considered and processed and analysed in ArcGIS software using surface tool of spatial analyst. On the contrary, the thematic layers of geomorphology, lithology and soil of the study of interest are reproduced extracting them from the maps of GSI and NBSS\&LUP employing editor tool of ArcGIS software. The LULC map is prepared classifying the OLI image in different LULC types in Erdas Imagine software adopting maximum likelihood algorithm of supervised classification.

\section{AHP Model and Its Application}

The application of Multi-Criterion Decision Analysis (MCDA) is used successfully in various disciplines for years (Schmoldt 2011; Guaita-Martínez et al. 2019; Ghosh et al. 2020a; Salabun 2020; Karmakar et al. 2021). The AHP model, developed by T. Saaty in 1980 (Ghosh et al. 2020a; Karmakar et al. 2021), is one of the popular and widely accepted methods in MCDA because of its multidimensional application in several fields in case of decision making (Akadiri and Olomolaiye 2012; Waris et al. 2019; Ghosh et al. 2020a; Karmakar et al. 2021), and the model can simplify the complexity of problems based on best possible opinions of experts (Punniyamoorty et al. 2012; Celik 2019; Ghosh et al. 2020a; Karmakar et al. 2021). The selected ten factors, which are mutually related to each other, responsible for gully erosion are analysed adopting AHP model to assign weight to each factor and their sub-classes depending upon the role of each factor in the process of gully erosion. To quantify weight numerically of any factor based on its relative importance in a whole event is most significant 
quality of AHP model (Waris et al. 2019; Ghosh et al. 2020a; Karmakar et al. 2021). The Consistency Index (CI), an important aspect of AHP, facilitates to validate the judgement score assigned by decision makers (Saaty and Vargas 1982; Ghosh et al. 2020a). There are four steps involved to run the AHP model, such as assigning weight, pair-wise comparison matrix, weight normalization and consistency assessment (Benjmel et al. 2020; Ghosh et al. 2020a). The selected ten parameters are first arranged in hierarchical order considering priorities to assign weight based on nine point scale (Table 1) devised by Saaty in 1980 , and each point of the scale defines some specific importance (Saaty 1990). The process of weight assignment is conducted based on literature review and proper field investigation (Ghosh et al. 2020a; Karmakar et al. 2021). In second step to compare all the factors with each other, a pair-wise comparison matrix $(W)$ is done (equation 1$)$. To obtain the normalization of weight $\left(W_{i j}\right)$ from matrix table (Table 2), the equation 2 is employed following the eigen vector technique of Saaty (Neissi et al. 2020; Ghosh et al. 2020a; Karmakar et al. 2021), and p represents geometric mean of $i^{\text {th }}$ factor.

$$
W=\left|\begin{array}{ccc}
f_{13} & f_{14} \cdots & f_{1 n} \\
f_{23} & f_{24} \cdots & f_{2 n} \\
f_{n 1} & f_{n 2} \cdots & f_{n n}
\end{array}\right|
$$

$$
W_{i j}=\frac{p}{\sum p}
$$

2

To verify the judgement coherence, the Consistency Ratio (CR) is developed (equation 3), and it is derived dividing Cl from Random Consistency Index (RCI). In order to allow the judgement value, the $\mathrm{CR}$ value required to be less than 0.1 , else new comparison matrix needs to be computed assigning fresh judgement values to all factors till the CR value does not reach to less than 0.1 (Ghosh et al. 2020; Karmakar et al. 2021). The mathematical expression used in calculating $\mathrm{Cl}$ is denoted by equation 4 . Here, $n$ depicts number of factors taken into consideration, and $\lambda_{\max }$ describes principal eigen value (Saaty 1990 ).

$$
C R=\frac{C I}{R C I}
$$

3

$C l=\frac{(\lambda \max -n)}{n-1}(4)$

\section{Computation of Gully Erosion Susceptibility Zone Index and Accuracy Assessment}

The computation of Gully Erosion Susceptibility Zone Index (GESZI) is performed taking in to account all the thematic layers of ten factors and this done by map algebra tool of in ArcGIS software using weighted linear combination method. Following equation (5) is adopted to calculate GESZI. Here, $f_{w}$ refers weight of each factor and $f_{r}$ denotes rank of sub-classes. The final output of Gully Erosion Susceptible Zone (GESZ) is generated from ArcGIS software involving all the parameters. The value of GESZI is dimensionless and derived GESZI values are categorized into five distinct classes, namely: very low, low, moderate, high and very high following natural break classification system of ArcGIS software. To validate the map of GESZ, the overall all accuracy assessment is carried out in conformity of the studies areas. Finally, a flow chart is prepared to portray the details of methodology (Fig. 2).

GESZI $=\sum_{i}^{n}\left(f_{W} \times f_{r}\right)(5)$

Table 1 is near here

Table 2 is near here

Table 3 is near here

Figure 2 is near here

Description of Factors of Soil Erosion and Gully Formation

\section{Geomorphology}

Geomorphology is the study of landforms including its evolution, classification and several geomorphic processes acting upon them (Summerfield 1991; Huggett 2007; Karmakar 2021). Understanding of geomorphology helps to assess the landscape more precisely (Murmu et al. 2019; Karmakar et al. 2021). Geomorphologically the Rupai basin area can be divided into six sub-classes based on existing landforms (Fig. 3). The north, west and south western portions of the river basin are characterized by pediplain (36.64\%) followed by dissected hills and valleys (30.36\%) and pediment (24.26\%). The rest of the landforms do not significantly dominate in the river basin. Among the sub-classes of geomorphology, the dissected hills and valleys obtain highest weight (0.286) followed by residual hill (0.238) and pediment (0.19), while valley fill secures lowest weight of 0.048 due to its lower level of elevation compared to other landforms of in the study area (Table 3). Dandapat et al. (2020) observed almost same situation in case of Dulung river basin of west Bengal.

Figure 3 is near here

Slope

Page $4 / 19$ 
In the process of soil erosion in the form of rills and gullies, slope plays a crucial role. Slope simply may defined as the variation of elevation on topography in a certain space (Yeh et al. 2016; Guru et al. 2017; Ghosh et al. 2020a, b). There is an inverse relation of degree of slope with infiltration rate and directly proportional to surface run-off (Siva et al. 2017; Karmakar et al. 2021). Higher degree of slope augments the soil erosion in the form of rill and gully (Conforti et al. 2011). The study area exhibits undulating topography with varying degree of slopes. The general geological slope of the basin is west to east and southeast ward (Fig. 4). Most of the basin area (71.87\%) is experienced low degree of slope (i.e. less than 3 degree) and extended predominantly north, west and south-west portion of the basin. The moderate degree of slope (3-9 degree) covers an area of $15.58 \%$. An area of $12.55 \%$ belongs to high to very high degree of slope. Higher degree of slope is found mainly at eastern and south-eastern portions. There are some residual hills situated in the basin, namely: Lagamburu, Jajahatu and Gajaburu (Jhalda-I), and Bansa and Shikra (Jhalda-II), which are also seen in the same directions. The weight value for sub-categories ranges in between 0.18 to 0.21 (Table 3). Different studies revealed that higher degree of slope increases the surface run-off with higher velocities and results in disintegration of soil particles and its transportation (Conforti et al. 2011; Zabihi et al. 2017; Yang et al. 2021; Dandapat et al. 2020). This situation gets worsened in absence of vegetation cover (Yang et al. 2021).

\section{Figure 4 is near here}

\section{Land Use and Land Cover}

The LULC plays a significant role in the process of gully erosion (Conforti et al. 2011; Yang et al. 2021). A number of variables, such as run-off rate, infiltration, surface water, soil moisture and water holding capacity etc., are influenced by LULC (Singh et al. 2018; Ghosh et al. 2020a; Karmakar et al. 2021). The presence of vegetation cover significantly decreases the erosive action of surface run-off and gully erosion susceptibility (Conforti et al. 2011). The study area mostly possesses fallow land (36.45\%) followed by vegetation cover (33.48\%). Hilly surface with dense forest is computed to be $18.67 \%$. The lowest proportion of basin $(1.34 \%)$ is covered by built up are and others (Table 3 ). Vegetation cover and hilly surface with dense forest dominate eastern and southeastern portion of the river basin, while fallow land and agricultural fallow land are observed in western and middle portion of the basin (Fig. 5). The higher weight value is obtained by fallow land, agricultural fallow land and built up area (Table 3). It is mentioned by several researchers that fallow lands (Conforti et al. 2011), agricultural fallow lands (Dandapat et al. 2020) and range area (Arabameri et al. 2018). It is evident that open spaces with steepness are more susceptible to gully erosion.

\section{Figure 5 is near here}

\section{Soil}

The physical properties of soil highly influence the rate of surface run-off, infiltration capacity, resistivity to soil erosion as well initiation of gully formation. Soil texture is a function of sub-surface flow and piping, and the formation of gullies starts when the top of the pipes falls down (Igwe et al. 2020). The study of interest mainly forms four consecutively four distinct soil group from west to east (Fig. 6). Fine soil mainly dominates (40.49\%), while gravelly loamy extends around $4.19 \%$. The rest of the proportion is covered by fine loamy to fine loamy - coarse loamy (Table 3). Fine soil is mainly susceptible to erosion (Dandapat et al. 2020) and it is also reflected by the weight value of sub-classes of soil (Table 3).

\section{Figure 6 is near here}

\section{Stream Power Index}

It is a measure to understand the erosive power of surface water flow considering the simple assumption that the discharge is proportional to the specified catchment area. This measure is important because river incision and slope toe erosion are directly influenced by the power of running water (Conforti et al. 2011). Around $78 \%$ of the basin area comes under the category of -0.04 to 0.0 , where -0.21 to -0.04 and 0.0 to -0.02 sub-classes share around $9 \%$ area by each of them. The lowest value ( $0.67 \%$ ) belongs to 0.05 to 0.18 (Table 3). Broadly, the basin is divided into, west and certain portion of east (Fig. 7 ). The areas with high SPI may experience greater possibility of erosion (Conforti et al. 2011; Arabameri et al. 2018).

\section{Figure 7 is near here}

\section{Curvature}

The bend of topographic surface from a horizontal plain is termed as curvature. Based on the shape of bends of topographic surface, the convex profile is referred when it is curved upward and concave while it is curved downward (Conforti et al. 2011; Karmakar et al. 2021). A significant proportion of the basin (47.82\%) is flat followed by concavity of topography (36.64\%). The share of convex curvature is observed to be $17.54 \%$ (Table 3 ), and it is found west and south-western directions due to presence residual hills and pediments (Fig. 8). The study of curvature helps to realize gully initiation and development. The presence of higher amount of concave curvature expedites the process of gully erosion (Conforti et al. 2011; Zabihi et al. 2017).

\section{Figure 8 is near here}

\section{Lithology}

The occurrence of gully significantly depends on lithological properties. The geological map gives impression of underlying lithology (Igwe et al. 2020). The river basin owns different types of rocks of different geological formations from Proterozoic to Quaternary (Karmakar et al. 2021). The dominating rocks are found here $(72.10 \%)$ granite gneiss followed by biotite gneiss and granite. Unclassified soil and alluvium account for $2.50 \%$ (Table 3 ). The map of the basin shows that granite and gneiss spread from west and north to east direction (Fig. 9). Unconsolidated and well exposed materials are suitable for gully formation (Conforti et al. 2011). The presence of unclassified soil and alluvium of quaternary and recent deposits are highly susceptible to gully erosion. 


\section{Elevation}

The river basin is situated at CGGS, a hard rock plateau region, and elevation map depicts moderately spacing contour due to presence of several residual hills (Fig. 10). The highest share of the basin (35.43\%) belongs to the range of elevation of 228 to $268 \mathrm{~m}$ followed by 181 to $228 \mathrm{~m}$ (31.71\%), while around $16 \%$ area comes under 326 to $645 \mathrm{~m}$ elevation. The study reveals that moderate to high elevated areas are more prone to erosion (Table 3 ). Several other works also pointed out in this regard (Arabameri et al. 2018; Yang et al. 2021).

\section{Figure 10 is near here}

\section{Drainage Density}

Within a unit of area, the total length of streams is known as drainage density. It is also referred as closeness of stream spacing and influenced by a number of variables, such as slope, lithology, soil, vegetation cover, rainfall etc., (Ghosh et al. 2020a; Karmakar et al. 2021). This indicator influences soil, rill and gully erosion (Dandapat et al. 2020). The higher drainage density is observed towards higher elevated and sloping areas (Fig. 11) and ranges from 0.47 to 0.89 (31.30\%) and 0.89 to 1.31 (29.85\%) followed by 1.31 to 1.74 (Table 3). The weight value enhances with increasing drainage density (Dandapat et al. 2020; Yang et al. 2021).

\section{Figure 11 is near here}

\section{Topographic Wetness Index}

This is a measure to perceive the topographical control over hydrological process (Igwe et al. 2020). It is calculated taking into account the possibility of storing of water in a certain area of the basin with the probability of moving of water following the gravity (Karmakar et al. 2021). The higher value of TWI indicates greater risk of susceptibility of soil erosion and subsequent formation of related landforms. It is also documented by Conforti et al. (2010), Arabameri et al. (2018) and Igwe et al. (2020). The lower basin area (14.82\%) lies in between the range of 11.76 to 22.28 . The study finds relatively low importance of TWI (Table 3). Areas belonging to east to west experience lower TWI (Fig. 12).

\section{Figure 12 is near here}

\section{Gully Erosion Susceptibility Zone}

The integration of geospatial techniques and AHP model employing all the ten selected factors facilitates to generate the GESZM of Rupai river basin. The GESZ is classified in five distinct classes adopting natural break classification system of ArcGIS software (Table 4). The area falls under low to moderate group of GESZ is $51.71 \%$ based on dimensionless value of GESZ. Very low GESZ is found to be $19.72 \%$. On the contrary, the values of high and very high GESZ are $19.88 \%$ and $8.68 \%$ respectively. High to very high GESZ is observed scattered way in some portion of middle of the basin and west to south-west margin (Fig. 13).

\section{Table 4 is near here}

\section{Figure 13 is near here}

\section{Accuracy Assessment of Gully Erosion Susceptibility Zone Map}

To know reliability of the derived GESZ based on GESZ map, the accuracy assessment is a prerequisite condition towards the validation of the model. In order to do the same, a total number of eleven sites are visited to investigate the ground truth reality based on available literatures and observation of Google Earth Pro software for selection of suitable sites across the entire basin (Fig. 14). The Keyhole Markup Language (KML) file is prepared in Google Earth Pro and overlaid on GESZ map. The overlaid sites of investigated are now distributed on GESZ map, and found the frequency of site numbers locating in different classes of GESZ. The total sites of investigation with susceptibility to gully erosion moderate to very high is now summed up and divided from total number of sites. The derived result is multiplied by hundred. Finally, the level of accuracy assessment is computed to be $72.72 \%$ (Table 5), which is very high and advocates for the derived GESZ map.

\section{Table 4 is near here}

\section{Figure 14 is near here}

\section{Estimation of Gully Erosion}

The total loss of soil from the three studied gullies is estimated using the simple calculation. These three gully sites of the river basin are namely: Kutidih (23 ${ }^{\circ}$

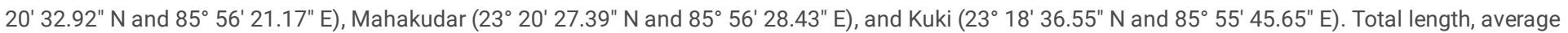
width and depth of gullies $(\mathrm{m})$ are computed to obtain the total volume of all gullies (Plate 1). The bulk density of laterite soil for Rarh Bengal is calculated by Ghosh et al. (2021b) as $2.205 \mathrm{gm} \mathrm{cm}^{-3}$ up to $1.45 \mathrm{~m}$ depth. Now, the volume of gully is multiplied by average bulk density of laterite. The estimated value of the weight of eroded materials from gullies of Kutidih, Mahakudar and Kuki are calculated to be 6.09 tonne, 40.96 tonne and 1.40 tonne respectively.

\section{Plate 1 is near here}




\section{Conclusion}

Assessment of susceptibility to gully erosion involves a huge time and labour when geol-physical investigation is carried out for a large watershed or basin. In this research work, integrating geospatial technology with AHP model helps to assess the zones of gully erosion. Moreover, the field visits also enhances the reliability of the investigation and preparation of mapping. This study reveals that geomorphology, slope, LULC, soil and SPI are the most influential factors in the process of soil erosion and gully formation. Around $52 \%$ of the basin area is susceptible to gully erosion. Some sites have also been experiencing a huge soil loss in the form of severe gully erosion. Seasonal field visits around the year with precise investigation, the study may yield more suitable results.

\section{Declarations}

\section{Acknowledgment}

The authors are thankful to Sk, Firoz for his constant support during the field investigation.

\section{Authors' contributions}

PM conducted field work, collected secondary data, analysed it and partially drafted the first manuscript. MM formulated the idea of the work, conducted field, partially drafted and critically revised the manuscript. SM conducted field and partially drafted the manuscript. BG helped in analysing data and revision of manuscript.

\section{Ethical approval}

Not applicable

\section{Consent to participate}

Not applicable

\section{Consent to publish}

Not applicable

\section{Competing Interest}

The authors declare no competing of interest.

\section{Funding}

This research work does receive any funding from any institutions or organizations.

\section{Data availability}

Not applicable

\section{References}

1. A Comparative Study for Landslide Susceptibility Mapping Using GIS-Based Multi-Criteria Decision Analysis (MCDA), Logistic Regression (LR) and Association Rule Mining (ARM).', n.d.

2. Akgun A., Turk N. 'Mapping Erosion Susceptibility by a Multivariate Statistical Method: A Case Study from the Ayvalık Region, NW Turkey.' Compute Geosci 37 (2011): 1515-24.

3. Althuwaynee, F.O, B Pradhan, and S Lee. "'Application of an Evidential Belief Function Model in Landslide Susceptibility Mapping."' Computers \& Geosciences, 44 (2012): 120-35. https://doi.org/10.1016/j.cageo.2012.03.003.

4. Amiri M, Pourghasemi HR, Ghanbarian GA, Afzali SF. 'Assessment of the Importance of Gully Erosion Effective Factors Using Boruta Algorithm and Its Spatial Modelling and Mapping Using Three Machine Learning Algorithms.' Geoderma 340 (2019): 55-69.

5. Anabalagan R. 'Landslide Hazard Evaluation and Zonation Mapping in Mountainous Terrain.' 32 (1992): 269-77.

6. Arabameri, A, Khalil Razaei, H.R. Pourghasemi, Saro Lee, and Mojtaba Yamani. 'GIS-Based Gully Erosion Susceptibility Mapping: A Comparison among Three Data-Driven Models and AHP Knowledge-Based Technique'. Environmental Earth Sciences 77, no. 17 (2018): 628. https://doi.org/10.1007/s12665018-7808-5.

7. Assefa E, and Hans-Rudolf B. 'Farmers' Perception of Land Degradation and Traditional Knowledge in Southern Ethiopia-Resilience and Stability.' Land Degradation and Development., 2016. https://doi.org/10.1002/ldr.2364.

8. Ayalew, L., H. Yamagishi, and N. Ugawa. 'Landslide Susceptibility Mapping Using GIS-Based Weighted Linear Combination, the Case in Tsugawa Area of Agano River, Niigata Prefecture, Japan.', Landslides, 1, no. 1 (2004): 73-81.

9. Ayele, G. K., Gessess, A. A., Addisie, M. B., Tilahun, S. A., Tenessa, D. B., Langendoen, E. J., et al. 'The Economic Cost of Upland and Gully Erosion on Subsistence Agriculture for a Watershed in the Ethiopianhighlands.' African Journal of Agricultural and Resource Economics, 10, no. 4 (2015): $265-78$. 
10. Benjmel, K., Amraoui, F., Boutaleb, S., Ouchchen, M., Tahiri, A., Touab, A.,. 'Mapping of Groundwater Potential Zones in Crystalline Terrain Using Remote Sensing, GIS Techniques, and Multicriteria Data Analysis (Case of the Ighrem Region, Western Anti-Atlas, Morocco).' Water $12,(2020)$ : 471. https://doi.org/10.3390/w12020471.

11. Bennet SJ, Casali J, Robinson KM, Kadavy KC. 'Characteristics of Actively Eroding Ephemeral Gullies in an Experimental Channel.' Transactions of the American Society of Agricultural Engineers 43 (2000): 641-49.

12. Besler, H. 'Slope Properties, Slope Processes and Soil Erosion Risk in the Tropical Rain Forest of Kalimantan Timur (Indonesian Borneo).' Earth Surface Processes and Landforms 12, no. 2 (1987): 195-204.

13. Bijukchhen, S.M., P. Kayastha, and M.R. Dhital. 'A Comparative Evaluation of Heuristic and Bivariate Statistical Modelling for Landslide Susceptibility Mappings in Ghurmi-Dhad Khola, East Nepal.' Arabian Journal of Geosciences 6, no. 8 (2013): 2727-43.

14. Bufalo M, Nahon D. 'Erosional Processes of Mediterranean Badlands: A New Erosivity Index for Predicting Sediment Yield from Gully Erosion.' Geoderma 52 (1992): 133-47.

15. Burkard MB., Kostaschuk RA. 'Patterns and Controls of Gully Growth along the Shoreline of Lake Huron.' Earth Surf Process Landf 22 (1997): $901-911$.

16. C, evik E, Topal T. 'GIS-Based Landslide Susceptibility Mapping for a Problematic Segment of the Natural Gas Pipeline, Hendek (Turkey).' Environ Geol 44 (2003): 949-62.

17. Çelik, R., 'Evaluation of Groundwater Potential by GIS-Based Multicriteria Decision Making as a Spatial Prediction Tool: Case Study in the Tigris River Batman-Hasankeyf Sub-Basin.' Water 11, (2019): 2630.

18. Chakrabarty, A. 'Ecotourism Development and Security Restructuring: A GIS Based Planning for Peaceful Dissuasion of Anarchism in Forest Provinces of India'. Procedia-Social and Behavioral Sciences, 21 (2011): 108-15. https://doi.org/10.1016/j.sbspro.2011.07.006.

19. Chaplot V., Coadou le Brozec E., Silvera N., Valentin C. 'Spatial and Temporal Assessment of Linear Erosion in Catchments under Sloping Lands of Northern Laos.' Catena 63 (2005): 167-184.

20. Choi Y., Park H., Sunwoo C. 'Flood and Gully Erosion Problems at the Pasir Open Pit Coal Mine, Indonesia: A Case Study of the Hydrology Using GIS'. Bull EngGeol Environ 67 (2008): 251-58.

21. Computers \& Geosciences. "'Application of the Analytical Hierarchy Process (AHP) for Landslide Susceptibility Mapping: A Case Study from the Tinau Watershed, West Nepal."' Computers \& Geosciences 52: (n.d.): 398-408. https://doi.org/doi:10.1016/j.cageo.2012.11.003.

22. Conforti M, Aucelli PC, Robustelli G, Scarciglia F. 'Geomorphology and GIS Analysis for Mapping Gully Erosion Susceptibility in the Turbolo Stream Catchment (Northern Calabria, Italy).' Nat Hazard 56 (2011): 881-98.

23. Conforti, M, P.C.P. Aucelli, G Robustelli, and F Scarciglia. 'Geomorphology and GIS Analysis for Mapping Gully Erosion Susceptibility in the Turbolo Stream Catchment (Northern Calabria, Italy)'. Natural Hazards, 56, no. 3 (2011): 881-98. https://doi.org/10.1007/s11069-010-9598-2.

24. Dai, F.C., and C.F. Lee. 'Landslide Characteristics and Slope Instability Modeling Using GIS, Lantau Island, Hong Kong.', Geomorphology, 42, no. 3-4 (2002): 213-228.

25. Dai FC, Lee CF, Li J, Xu ZW. 'Assessment of Landslide Susceptibility on the Natural Terrain of Lantau Island, Hong Kong.' Environ Geol 40 (2001): $381-91$.

26. Dandapat, Kishor, R Hazari, G.S. Bhunia, and P.K. Shit. 'The Potential Gully Erosion Risk Mapping of River Dulung Basin, West Bengal, India Using AHP Method'. In Gully Erosion Studies from India and Surrounding Regions, Advance in Science, Technology \& Innovation., 93-107. Springer, Cham, 2020. 10.1007/978-3-030-23243-6_6.

27. Das, B, R Bordoloi, L Thungon, Ashish Paul, Pankaj Pandey, M Mishra, and Om Tripathi. 'An Integrated Approach of GIS, RUSLE and AHP to Model Soil Erosion in West Kameng Watershed, Arunachal Pradesh'. J. Earth Syst. Sci. 129, no. 94 (2020): 2-18. https://doi.org/10.1007/s12040-020-1356-6.

28. Das, B, Ashish Paul, R Bordoloi, Om.P Tripathi, and P.K. Pandey. 'Soil Erosion Risk Assessment of Hilly Terrain through Integrated Approach of RUSLE and Geospatial Technology: A Case Study of Tirap District, Arunachal Pradesh."'. Modeling Earth Systems and Environment, 4, no. 1 (2018): $373-81$. https://doi.org/10.1007/s40808-018-0435-z.

29. de Neergaard, A., J. Magid, and O. Mertz. 'Soil Erosion from Shifting Cultivation and Other Smallholder Land Use in Sarawak, Malaysia.' Agriculture, Ecosystems \& Environment. 125, no. 1 (2008): 182-90.

30. DeRose RC, Gomez B, Marden M, Trustrum NA. 'Gully Erosion in Mangatu Forest, New Zealand, Estimated from Digital Elevation Models.' Earth Surface Processes and Landforms 23 (1998): 1045-53.

31. 'Development of Sustainable Assessment Criteria for Building Materials Selection.' Eng. Construct. Architect. Manag. 19 (2012): 666-87. https:// doi.org/10.1108/09699981211277568.

32. Dolui, Gour, Soumendu Chatterjee, and Nilanjana Das Chatterjee. 'Geophysical and Geochemical Alteration of Rocks in Granitic Profiles during Intense Weathering in Southern Purulia District, West Bengal, India'. Springer International Publishing Switzerland 2016 132, no. 2 (2016): 4-22. https://doi.org/10.1007/s40808-016-0188-5.

33. El Maaoui, M. A., Sfar Felfoul, M., Boussema, M. R., \& Snane, M. H. 'Sediment Yield from Irregularly Shaped Gullies Located on the Fortuna Lithologic Formation in Semi-Arid Area of Tunisia.' 93 (2012): 97-104.

34. Fadul, H.M., A.A. Salih, A.A. Imad-eldin, and S. Inanaga. 'Use of Remote Sensing to Map Gully Erosion along the Atbara River, Sudan. International Journal of Applied Earth Observation and Geoinformation' 1, no. 3 (1999): 175-180.

35. FAO. 'The Future of Food and Agriculture - Trends and Challenges.' Rome, 2017. http://www.fao.org/3/a-i6583e.pdf.

36. Ghosh, D., Mandal, M., Karmakar, M., Banerjee, M., \& Mandal, D. "'Application of Geospatial Technology for Delineating Groundwater Potential Zones in the Gandheswari Watershed, West Bengal."' Sustainable Water Resources Management, 6, no. 1 (b 2020): 14. https://doi.org/10.1007/s40899-020-00372-0. 
37. Ghosh, D, Manas Karmakar, Monali Banerjee, and Mrinal Mandal. 'Application of Geospatial Technology and Plant Diversity Indicies to Access the Temporal Change of Forest Cover across the Ajodhya Hills of West Bengal, India'. In Forest Resources Resilience and Conflicts, 139-51. Elseviers Inc $2021,2021$.

38. 'Evaluating the Rate of Change and Predicting the Future Scenario of Spatial Pattern Using Markov Chain Model: A Study from Baghmundi C.D. Block of Purulia District, West Bengal'. Società Italiana Di Fotogrammetria e Topografia (SIFET) 2020, c 2020. https://doi.org/10.1007/s12518-020-00345-0.

39. Ghosh, Sandipan, S.K Guchhait, R.A. Illahi, Subhankar Bera, and Suvendu Roy. "'Geomorphic Character and Dynamics of Gully Morphology, Erosion and Management in Laterite Terrain: Few Observations from Dwarka - Brahmani Interfluve, Eastern India."' Geology, Ecology, and Landscapes, n.d. https://doi.org/10.1080/24749508.2020.1812148.

40. Golestani, G., Issazadeh, L., \&Serajamani, R. 'Lithology Effects on Gully Erosion in Ghoorichay Watershed Using RS \& GIS.' Int J Biosci 4, no. 2 (2014): 7176.

41. Gómez Gutiérrez, Á., Schnabel, S., Lavado Contador, F.,. ‘Procesos, Factores y Consecuencias de La Erosión Por Cárcavas; Trabajos Desarrollados En La Península Ibérica.' Bol. Asoc. Geógr. Esp. 55, (2011): 59-80.

42. Gómez-Gutiérrez Á, Conoscenti C, Angileri SE, Rotigliano E, Schnabel S. 'Using Topographical Attributes to Evaluate Gully Erosion Proneness (Susceptibility) in Two Mediterranean Basins: Advantages and Limitations.' Nat Hazards 79, no. 1 (2015): 291-314.

43. Government of India. 'District Industrial Profile 2017-18 Purulia, Ministry of Micro, Small \& Medium Enterprises.', 2018.

44. 'Indian Census (2011)', n.d. http://censusindia.gov.in/.

45. Government of West Bengal. 'All India Livestock Census. 18th All India Livestock Census, Agriculture Implements \& Machinery, Fishery Statistics West Bengal, Purulia District, Part-I. Directorate of Animal Resources and Animal Health.', 2007.

46. Govers, G., Merckx, R., Wesemael, B.V., Van Oost, K. 'Soil Conservation in the 21st Century: Why We Need Smart Agricultural Intensification.', SOIL, 3 (2017): 45-59. https://doi.org/10.5194/soil-3-45-2017.

47. Guaita-Martínez, J.M., de Castro-Pardo, M., P erez-Rodríguez, F., Martín Martín, J.M., and 2019. Innovation and multi-level knowledge transfer using a multi-criteria decision. 'Innovation and Multi-Level Knowledge Transfer Using a Multi-Criteria Decisionmaking Method for the Planning of Protected Areas. Journal of Innovation \& Knowledge' 4 (2019): 256-61. https://doi.org/10.1016/j.jik.2019.01.001.

48. Guru, B, K Seshan, and S Bera. 'Requency Ratio Model for Groundwater Potential Mapping and Its Sustainable Management in Cold Desert, India.' J. King Saud Univ. Sci. 29 (2017): 333-47. https://doi.org/10.1016/.

49. Hosseinalizadeh, M.; Kariminejad, N.; Chen, W.; Pourghasemi, H.R.; Alinejad, M.; Behbahani, A.M.; Tiefenbacher, J.P. 'Gully Headcut Susceptibility Modeling Using Functional Trees, Naïve Bayes Tree, and Randomforest Models.' Geoderma 342 (2019): 1-11.

50. Huggett, R.J. 'Fundamentals of Geomorphology', Second. London, Madison Avenue, N.Y.: Routledge, 2007.

51. Ibáñez, J., Contador, J. L., Schnabel, S., \& Valderrama, J. M. 'Evaluating the Influence of Physical, Economic and Managerial Factors on Sheet Erosion in Rangelands of SW Spain by Performing a Sensitivity Analysis on an Integrated Dynamic Model.' Science of the Total Environ, 544, 2016, 439-49.

52. Igwe, O, L.U. Jhon, O Solomon, and O Obinna. 'GIS-Based Gully Erosion Susceptibility Modeling, Adapting Bivariate Statistical Method and AHP Approach in Gombe Town and Environs Northeast Nigeria'. Geoenvironmental Disasters, 7, no. 1 (2020): 32. https://doi.org/10.1186/s40677-020-00166-8.

53. Imeson, A.C., Kwaad, F.J.P.M.,. 'Gully Types and Gully Prediction. Geogr. Tijdschr.' 14 (1980): 430-441.

54. 'Impact of Hydro-Geological Environment on Availability of Groundwater Using Analytical Hierarchy Process (AHP) and Geospatial Techniques: A Study from the Upper Kangsabati River Basin.' Groundwater for Sustainable Development, a 2020. https://doi.org/10.1016/j.gsd.2020.100419.

55. Ionita, I., Fullen, M. A., Zgłobicki, W., \& Poesen, J. 'Gully Erosion as a Natural and Human-Induced Hazard. Natural Hazards', 79 , no. 1 (2015): 1-5. https://doi.org/https ://doi.org/10.1007/s1106 9-015-1935-z.

56. Kakembo V, Xanga WW, Rowntree K. 'Topographic Thresholds in Gully Development on the Hillslopes of Communal Areas in Ngqushwa Local Municipality, Eastern Cape, South Africa.' Geomorphology 110 (2009): 118-95.

57. Karmakar, Manas, Monali Banerjee, Mrinal Mandal, and D Ghosh. 'Application of AHP for Groundwater Potential Zones Mapping in Plateau Fringe Terrain: Study from Western Province of West Bengal'. In Groundwater and Society, 189-218. Springer Nature Swizerland AG 2021, n.d.

58. Kebede Y.S., Sinshaw, BG, Endalamaw NT., Atinkut, HB. 'Modeling Soil Erosion Using RUSLE and GIS at Watershed Level in the Upper Beles, Ethiopia.' Environmental Challenges 2, (2020): 100009.

59. Kirkby, M.; Bracken, L. 'Gully Processes and Gully Dynamics. Earth Surf. Process.' Landf. J. Br. Geomorphol. Res.Group. 34, (2009): $1841-51$.

60. Kirkby MJ, Bracken LJ. 'Gully Processes and Gully Dynamics. Earth Surface Processes Landforms'. J Br Geomorphological Res Group 34, no. 14 (2009): 1841-51.

61. Komac, M. 'A Landslide Susceptibility Model Using the Analytical Hierarchy Process Method and Multivariate Statistics in Perialpine Slovenia. Geomorphology.' 74, no. 1 (2006): 17-28.

62. Li, Xing, Yunxuan Zhou, Bo Tina, Runyuan Kuang, and Lihua Wang. 'GIS-Based Methodology for Erosion Risk Assessment of the Muddy Coast in the Yangtze Delta."'. Ocean \& Coastal Management, 108 (2015): 97-108. https://doi.org/10.1016/j.ocecoaman.2014.09.028.

63. Mandal, M., Modak, P., Karmakar, M., \& Ghosh, D. 'Tribal People of Purulia and Their Quality of Life. Eastern Geographer',Eastern Geographer, 24, no. 1 (2018): 126-135.

64. Martinez-Casasnovas JA, Anton-Fernandez C, Ramos MC. 'Sediment Production in Large Gullies of the Mediterranean Area (NE Spain) from HighResolution Digital Elevation Models and Geographical Information Systems Analysis.' Earth Surface Processes and Landforms 28 (2003): $443-56$. 
65. Martínez-Casasnovas, J.A., Ramos,M.C., Poesen, J.,. 'Assessment of Sidewall Erosion in Large Gullies Using Multi-Temporal DEMs and Logistic Regression Analysis', Geomorphology, 58, (2004): 305-321.

66. Moghaddam DD, Rezaei M, Pourghasemi HR, Pourtaghie ZS, Pradhan B. 'Groundwater Spring Potential Mapping Using Bivariate Statistical Model and GIS in the Taleghan Watershed, Iran.' Arab J Geosci 8, no. 2 (2015): 913-29.

67. Mohsen, Zabihi, M Fahimeh, M Alireza, K.D. Abdulvahed, R.P. Hamid, A.Z. Mohamad, and S Fatemeh. "'Spatial Modelling of Gully Erosion in Mazandaran Province, Northern Iran."' CATENA, 161 (2018): 1-13. https://doi.org/10.1016/j.catena.2017.10.010.

68. Moore ID, Grayson RB, Ladson AR. 'Digital Terrain Modelling: A Review of Hydrological, Geomorphological, and Biological Applications.' Hydrol Process 5 (1991): 3-30.

69. Murmu, P, M Kumar, and D Lal. 'Delineation of Groundwater Potential Zones Using Geospatial Techniques and Analytical Hierarchy Process in Dumka District, Jharkhand, India.' Groundwater for Sustainable Development 9, (2019): 100239. https://doi.org/10.1016/j.gsd.2019.100239.

70. Nasiri, M. 'GIS Modelling for Locating the Risk Zone of Soil Erosion in a Deciduous Forest'. JOURNAL OF FOREST SCIENCE, 59, no. 2 (2013): $87-91$.

71. Neaupane, K.M., and M. Piantanakulchai. 'Analytic Network Process Model for Landslide Hazard Zonation. Engineering Geology'. Engineering Geology 85, no. 3 (2006): 281-94.

72. Neissi, L., Albaji, M., Boroomand Nasab, S.,. 'Combination of GIS and AHP for Site Selection of Pressurized Irrigation Systems in the Izeh Plain, Iran. Agric.' Water Manag. 231 (2020): 106004. https://doi.org/10.1016/j.agwat.2020.106004.

73. Nekhay, O., M. Arriaza, and L. Boerboom. 'Evaluation of Soil Erosion Risk Using Analytic Network Process and GIS: A Case Study from Spanish Mountain Olive Plantations'. Journal of Environmental Management. 90, no. 10 (2009): 3091-3104.

74. Nyssen J., Poesen J., Moeyersons J., Luyten E., Veyret-Picot M, Deckers J., Haile M., Govers G. 'Impact of Road Building on Gully Erosion Risk: A Case Study from the Northern Ethiopian Highlands.' Earth Surf Process Landf 27 (2002): 1267-83.

75. Odunuga, S., Ajijola, A., Igwetu, N., Adegun, O.,. 'Land Susceptibility to Soil Erosion in Orashi Catchment, Nnewi South, Anambra State, Nigeria, Proc.', IAHS 376, 2018, 87-95. https://doi.org/10.5194/piahs-376-87-2018, 2018.

76. Onyando J O, Kisoyan P and Chemelil M C. 'Estimation of Potential Soil Erosion for River Perkerra Catchment in Kenya;Water Resour.' Manag. 19, no. (2) (2005): 133-43.

77. Palham Abbasi, A. 'Evaluation of Soil and Water Conservation Projects through Estimation of Erosion Intensity by Geomorphological Modelling (Case Study of Safaroud Watershed, Mazandaran Province, Iran)."'. Applied Ecology and Environmental Research, 15, no. 3 (2017): $1739-51$.

https://doi.org/10.15666/aeer/1503_17391751.

78. Patton, P.C., Schumm, S.A.,. 'Gully Erosion, North Western Colorado: A Threshold Phenomenon.', Geology, 31, (1975): $187-199$.

79. Pham, B.T., D.T. Bui, H.R. Pourghasemi, P. Indra, and M.B. Dholakia. 'Landslide Susceptibility Assessment in the Uttarakhand Area (India) Using GIS: A Comparison Study of Prediction Capability of Naïve Bayes, Multilayer Perceptron Neural Networks, and Functional Trees Methods' 2, no. 1 (2017): 25573.

80. Pimentel D. 'Soil Erosion: A Food and Environmental Threat.', 8:119-37. Environ Dev Sustain, 2006.

81. Poesen, J., Nachtergaele, J., Verstraeten, G., Valentin, C,. 'Gully Erosion and Environmental Change: Importance and Research Needs.', Catena, 50, (2003): 91-133.

82. Pourghasemi, H. R., A. G. Jirandeh, B. Pradhan, C. Xu, and C. Gokceoglu. "'Landslide Susceptibility Mapping Using Support Vector Machine and GIS at the Golestan Province, Iran."' Journal of Earth System Science 122 (2013): 349-369. https://doi.org/doi:10.1007/s12040-013-0282-2.

83. Pradeep, G. S., M. V. Ninu Krishnan, and H. Vijith. 'Identification of Critical Soil Erosion Prone Areas and Annual Average Soil Loss in an Upland Agricultural Watershed of Western Ghats, Using Analytical Hierarchy Process (AHP) and RUSLE Techniques."'. Arabian Journal of Geosciences, 8, no. 6 (2015): $3697-$ 3711. https://doi.org/10.1007/s12517-014-1460-5.

84. Punniyamoorty, M., Mathiyalagan, P., Lakshmi, G.,. 'A Combined Application of Structural Equation Modeling (SEM) and Analytic Hierarchy Process (AHP) in Supplier Selection.' Benchmark 19, (n.d.): 70-92. https://doi.org/10.1108/14635771211218362.

85. Rahaman, S. Abdul, and S. Aruchamy. "'Geoinformatics Based Landslide Vulnerable Zonation Mapping Using Analytical Hierarchy Process (AHP), a Study of Kallar River Sub Watershed, Kallar Watershed, Bhavani Basin, Tamil Nadu."' Modeling Earth Systems and Environment, 3, no. 1 (2017): 41. https://doi.org/10.1007/s40808-017-0298-8.

86. Rahmati O, Pourghasemi HR, Melesse AM. 'Application of GIS-Based Data Driven Random Forest and Maximum Entropy Models for Groundwater Potential Mapping: A Case Study at Mehran Region, Iran.' Catena 137 (2016): 360-72.

87. Rahmati, O.; Tahmasebipour, N.; Haghizadeh, A.; Pourghasemi, H.R.; Feizizadeh, B. 'Evaluation of Dierentmachine Learning Models for Predicting and Mapping the Susceptibility of Gully Erosion.' Geomorphology 298, (2017): 118-137.

88. Rodrigo-Comino J, Cerdà A. 'Improving Stock Unearthing Method to Measure Soil Erosion Rates in Vineyards.' Ecol Indicator 85 (2018): $509-17$.

89. Rozos, D., G. D. Bathrellos, and H. D. Skillodimou. 'Comparison of the Implementation of Rock Engineering System and Analytic Hierarchy Process Methods, upon Landslide Susceptibility Mapping, Using GIS: A Case Study from the Eastern Achaia County of Peloponnesus, Greece."'. Environmental Earth Sciences 63, no. 1 (2011): 49-63. https://doi.org/10.1007/s12665-010-0687-z.

90. Saaty, TL. 'How to Make a Decision: The Analytic Hierarchy Process'. European Journal of Operational Research 48, no. 1 (1990): $9-26$. https://doi.org/10.1016/0377-2217(90)90057-I.

91. Saaty, TL, and L.G. Vargas. 'The Logic of Prioritites: Application in Business, Energy, Health and Transportation.' International Series in Management Science/Operations Research, 1982.

92. Schmoldt, D.L. 'The Analytic Hierarchy Process in Natural Resource and Environmental Decision Making.' Springer, Dordrecht; London., 2011.

Page $10 / 19$ 
93. Singh SK, Laari PB, Mustak S et al. 'Modelling of Land Use Land Cover Change Using Earth Observation Data-Sets of Tons River Basin, Madhya Pradesh, India.' Geocarto Internationa33:, no. 1202-1222. (2018). https://doi.org/10.1080/10106049.2017.1343390.

94. Siva, G, N Nasir, and R Selvakumar. 'Delineation of Groundwater Potential Zone in Sengipatti for Thanjavur District Using Analytical Hierarchy Process.' IOP Conf. Ser. Earth Environ. Sci. 80 (2017): 012063. https://doi.org/10.1088/1755-1315/80/1/012063.

95. Summerfield M (. 'Global Geomorphology: An Introduction to the Study of Landforms.' [Harlow, Essex, England)]: [Longman Scientific \& Technical]; New York, 1991.

96. Swarnkar, S., Malini, A., Tripathi, S., Sinha, R., 'Assessment of Uncertainties in Soil Erosion and Sediment Yield Estimates at Ungauged Basins: An Application to the Garra River Basin, India.' Hydrol. Earth Syst. Sci. 22 (2018): 2471-85. https://doi.org/10.5194/hess-22-2471-2018.

97. Takken I., Croke J., Lane P. 'Thresholds for Channel Initiation at Road Drain Outlets'. Catena 75 (2008): 257-267.

98. Thomas, Jobin, Sabu Joseph, and K.P. Thrivikramji. "'Assessment of Soil Erosion in a Monsoon-Dominated Mountain River Basin in India Using RUSLESDR and AHP."' Hydrological Sciences Journal, 63, no. 4 (2018): 542-60. https://doi.org/10.1080/02626667.2018.1429614.

99. Thornbury, W.D. 'Principles of Geomorphology.', 2nd ed. New York: Wiley., 1969.

100. Tilahun SA., Guzman CD., Zegeye AD., Ayana ES., Collick AS., Yitaferu B., Steenhuis TM. 'Spatial and Temporal Patterns of Soil Erosion in the Semi-Humid Ethiopian Highlands: A Case Study of Debre Mawi Watershed. In: Melesse A., Abtew W., Setegn S. (Eds) Nile River Basin.' .. Springer, Cham., 2014. https://doi.org/10.1007/978-3-319-02720-3_9.

101. Torri, D., Poesen, J., Borselli, L., Bryan, R., Rossi, M., 'Spatial Variation of Bed Roughness in Eroding Rills and Gullies.' Catena 90, (2012): 76-86.

102. 'Use of Terrain Variables for Mapping Gully Erosion Susceptibility in Lebanon'. Earth Surface Processes and Landforms, 32, no. 12 (2007): $1770-82$. https://doi.org/10.1002/esp.1501.

103. Valentin, C., Poesen, J., Li, Y.,. 'Gully Erosion: Impacts, Factors and Control.', Catena, 63, (2005): 132-153.

104. Valentin C., Poesen J., Yong L. 'Gully Erosion: Impacts, Factors and Control.' Catena 63 (2005): 132-53.

105. Vijith, H., and D. Dodge-Wan. 'Spatio-Temporal Changes in Rate of Soil Loss and Erosion Vulnerability of Selected Region in the Tropical Forests of Borneo during Last Three Decades.' Earth Science Informatics. 11, no. 2 (n.d.): 171-81.

106. Vrieling A. 'Satellite Remote Sensing for Water Erosion Assessment: A Review.' Catena, 65, no. 1 (2006): 2-18. https://doi.org/10.1016/j.catena.2005.10.005.

107. Waris, M, S Panigrahi, A Mengal, M.I. Soomro, N.H. Mirjat, N.H., Ullah, M., Azlan, Z.S., and Khan, A.,. 'An Application of Analytic Hierarchy Process (AHP) for Sustainable Procurement of Construction Equipment: Multicriteria-Based Decision Framework for Malaysia."'. Mathematical Problems in Engineering, 2019 (September 2019): 1-20. https://doi.org/10.1155/2019/6391431.

108. Wilson JP, Gallant JC. 'Terrain Analysis Principles and Applications.', 479. Toronto Canada,: Wiley, 2000.

109. Xia D, Deng Y, Wang S, Ding S, Cai C. 'Fractal Features of Soil Particle-Size Distribution of Different Weathering Profiles of the Collapsing Gullies in the Hilly Granitic Region, South China.' Nat Hazards 79, no. 1 (2015): 455-78.

110. Yalcin, A. 'GIS-Based Landslide Susceptibility Mapping Using Analytical Hierarchy Process and Bivariate Statistics in Ardesen (Turkey): Comparisons of Results and Confirmations.' 72, no. 1 (2008): 1-12.

111. Yang, A, C Wang, G Pang, Y Long, L Wang, R.M. Cruse, and Q Yang. “'Gully Erosion Susceptibility Mapping in Highly Complex Terrain Using Machine Learning Models.' ISPRS International Journal of Geo-Information 10, no. 10 (2021): 680. https://doi.org/10.3390/ijgi10100680.

112. Yeh, H.-F., Y.-S. Cheng, H.-I. Lin, and C.-H Lee. 'Mapping Groundwater Recharge Potential Zone Using a GIS Approach in Hualian River, Taiwan.' Sustainable Environment Research 26 (2016): 33-43. https://doi.org/10.1016/j.serj.2015.09.005.

113. Yoshimatsu, H., and S. Abe. 'A Review of Landslide Hazards in Japan and Assessment of Their Susceptibility Using an Analytical Hierarchic Process (AHP) Method'. Landslides 3, no. 2 (2006): 149-58.

114. Youssef, Feras, S Visser, D Karssenberg, A Bruggeman, and G Erpul. 'Calibration of RWEQ in a Patchy Landscape; a First Step towards a Regional Scale Wind Erosion Model.' Aeolian Research 3 (2012): 467-76. https://doi.org/10.1016/j.aeolia.2011.03.009.

115. Zakerinejad R, Maerker M. 'An Integrated Assessment of Soil Erosion Dynamics with Special Emphasis on Gully Erosion in the Mazayjan Basin, Southwestern Iran.' Nat Hazards., n.d., 2015. https://doi.org/10.1007/s11069-015-1700-3.

116. Zakerinejad, R.; Maerker, M. 'An Integrated Assessment of Soil Erosion Dynamics with Special Emphasis Ongully Erosion in the Mazayjan Basin, Southwestern Iran.' Nat. Hazards 79, (2015): 25-50.

117. Zhou P, Luukkanen O, Tokola T and Nieminen J. 'EAect of Vegetation Cover on Soil Erosion in a Mountainous Watershed'; Catena 75, no. 3 (2008): 319 325.

118. Zucca, C., Canu, A., Della Peruta, R.,. 'Effects of Land Use and Landscape on Spatial Distribution and Morphological Features of Gullies in an Agropastoral Area in Sardinia (Italy).' Catena 68, (2006): 87-95.

\section{Tables}

Table 1 Saaty's nine-point Scale and random consistency index 


\begin{tabular}{|llllllllll|}
\hline $\begin{array}{l}\text { Intensity of importance on an absolute } \\
\text { scale }\end{array}$ & 1 & 2 & 3 & 4 & 5 & 6 & 7 & 8 \\
\hline $\begin{array}{l}\text { Definition } \\
\text { Number of factors }\end{array}$ & Equal & Weak & Moderate & $\begin{array}{l}\text { Moderate } \\
\text { Plus }\end{array}$ & Strong & $\begin{array}{l}\text { Strong } \\
\text { Plus }\end{array}$ & $\begin{array}{l}\text { Very } \\
\text { Strong }\end{array}$ & $\begin{array}{c}\text { Very Very } \\
\text { Strong }\end{array}$ & $\begin{array}{c}\text { Extreme } \\
\text { RCl }\end{array}$ \\
\hline
\end{tabular}

Table 2 Pair-wise comparison matrix of ten influencing factors and their normalized weight

\begin{tabular}{|c|c|c|c|c|c|c|c|c|c|c|c|c|}
\hline Factors & Geomorphology & Slope & LULC & Soil & $\begin{array}{l}\text { Stream } \\
\text { power } \\
\text { index }\end{array}$ & $\begin{array}{l}\text { Profile } \\
\text { curvature }\end{array}$ & Lithology & Elevation & $\begin{array}{l}\text { Drainage } \\
\text { density }\end{array}$ & TWI & $\begin{array}{l}\text { Geometric } \\
\text { mean }\end{array}$ & $\begin{array}{l}\text { Normalize } \\
\text { weight }\end{array}$ \\
\hline Geomorphology & $9 / 9$ & $9 / 8$ & $9 / 7$ & $9 / 7$ & $9 / 6$ & $9 / 5$ & $9 / 4$ & $9 / 3$ & $9 / 3$ & $9 / 2$ & 1.85 & 0.167 \\
\hline Slope & $8 / 9$ & $8 / 8$ & $8 / 7$ & $8 / 7$ & $8 / 6$ & $8 / 5$ & $8 / 4$ & $8 / 3$ & $8 / 3$ & $8 / 2$ & 1.64 & 0.148 \\
\hline LULC & $7 / 9$ & $7 / 8$ & $7 / 7$ & $7 / 7$ & $7 / 6$ & $7 / 5$ & $7 / 4$ & $7 / 3$ & $7 / 3$ & $7 / 2$ & 1.44 & 0.130 \\
\hline Soil & $7 / 9$ & $7 / 8$ & $7 / 7$ & $7 / 7$ & $7 / 6$ & $7 / 5$ & $7 / 4$ & $7 / 3$ & $7 / 3$ & $7 / 2$ & 1.44 & 0.130 \\
\hline $\begin{array}{l}\text { Stream power } \\
\text { index }\end{array}$ & $6 / 9$ & $6 / 8$ & $6 / 7$ & $6 / 7$ & $6 / 6$ & $6 / 5$ & $6 / 4$ & $6 / 3$ & $6 / 3$ & $6 / 2$ & 1.23 & 0.111 \\
\hline Curvature & $5 / 9$ & $5 / 8$ & $5 / 7$ & $5 / 7$ & $5 / 6$ & $5 / 5$ & $5 / 4$ & $5 / 3$ & $5 / 3$ & $5 / 2$ & 1.03 & 0.093 \\
\hline Lithology & $4 / 9$ & $4 / 8$ & $4 / 7$ & $4 / 7$ & $4 / 6$ & $4 / 5$ & $4 / 4$ & $4 / 3$ & $4 / 3$ & $4 / 2$ & 0.82 & 0.074 \\
\hline Elevation & $3 / 9$ & $3 / 8$ & $3 / 7$ & $3 / 7$ & $3 / 6$ & $3 / 5$ & $3 / 4$ & $3 / 3$ & $3 / 3$ & $3 / 2$ & 0.62 & 0.056 \\
\hline $\begin{array}{l}\text { Drainage } \\
\text { density }\end{array}$ & $3 / 9$ & $3 / 8$ & $3 / 7$ & $3 / 7$ & $3 / 6$ & $3 / 5$ & $3 / 4$ & $3 / 3$ & $3 / 3$ & $3 / 2$ & 0.62 & 0.056 \\
\hline TWI & $2 / 9$ & $2 / 8$ & $2 / 7$ & $2 / 7$ & $2 / 6$ & $2 / 5$ & $2 / 4$ & $2 / 3$ & $2 / 3$ & $2 / 2$ & 0.41 & 0.037 \\
\hline
\end{tabular}

Source: Saaty's $C R=(<0.1) ; C R=0.000000079$, the computed matrix is accepted based on derived $C R$ value

Table 3 Classification of factors and the rank of sub-classes on the basis of influencing capacity in susceptibility in gully erosion 


\begin{tabular}{|c|c|c|c|c|c|}
\hline Factors & Normalized weight & Sub-classes & Area (\%) & Normalized weight & Rank \\
\hline \multirow[t]{6}{*}{ Geomorphology } & \multirow[t]{6}{*}{0.167} & Valley fill & 4.93 & 0.05 & 1 \\
\hline & & Inselberg & 0.95 & 0.14 & 3 \\
\hline & & Pediment & 24.26 & 0.19 & 4 \\
\hline & & Pediplain & 36.64 & 0.10 & 2 \\
\hline & & Residual hill & 0.87 & 0.24 & 5 \\
\hline & & Dissected hills and valleys & 30.36 & 0.29 & 6 \\
\hline \multirow[t]{4}{*}{ Slope (degree) } & \multirow[t]{4}{*}{0.148} & $<3$ & 71.87 & 0.18 & 3 \\
\hline & & $3-9$ & 15.58 & 0.19 & 4 \\
\hline & & $9-17$ & 8.14 & 0.20 & 5 \\
\hline & & $>26$ & 4.41 & 0.21 & 6 \\
\hline \multirow[t]{5}{*}{ LULC } & \multirow[t]{5}{*}{0.130} & Hilly surface with dense forest & 18.67 & 0.05 & 1 \\
\hline & & Vegetation & 33.48 & 0.15 & 3 \\
\hline & & Fallow land & 36.45 & 0.35 & 7 \\
\hline & & Agricultural fallow land & 10.06 & 0.25 & 5 \\
\hline & & Built up area and others & 1.34 & 0.20 & 4 \\
\hline \multirow[t]{4}{*}{ Soil } & \multirow[t]{4}{*}{0.130} & Gravelly loamy & 4.19 & 0.07 & 1 \\
\hline & & Fine loamy to coarse loamy & 28.77 & 0.20 & 3 \\
\hline & & Fine loamy & 26.53 & 0.33 & 5 \\
\hline & & Fine & 40.49 & 0.40 & 6 \\
\hline \multirow[t]{5}{*}{ Stream power index } & \multirow[t]{5}{*}{0.111} & $-0.21--0.04$ & 9.30 & 0.05 & 1 \\
\hline & & $-0.04-0.00$ & 77.67 & 0.10 & 2 \\
\hline & & $0.00-0.02$ & 9.02 & 0.20 & 4 \\
\hline & & $0.02-0.05$ & 3.33 & 0.30 & 6 \\
\hline & & $0.05-0.18$ & 0.67 & 0.35 & 7 \\
\hline \multirow[t]{3}{*}{ Curvature } & \multirow[t]{3}{*}{0.093} & Convex & 17.54 & 0.60 & 6 \\
\hline & & Flat & 47.82 & 0.30 & 3 \\
\hline & & Concave & 34.64 & 0.10 & 1 \\
\hline \multirow[t]{7}{*}{ Lithology } & \multirow[t]{7}{*}{0.074} & Biotite gneiss & 19.66 & 0.14 & 4 \\
\hline & & Granite & 5.21 & 0.07 & 2 \\
\hline & & Granite gneiss & 72.10 & 0.11 & 3 \\
\hline & & Limestone \& impure marble & 0.32 & 0.18 & 5 \\
\hline & & Pegmatite vein & 0.06 & 0.04 & 1 \\
\hline & & Tuff, tuffaceous psammo-pelite & 0.12 & 0.21 & 6 \\
\hline & & Unclassified soil \& alluvium & 2.50 & 0.25 & 7 \\
\hline \multirow[t]{5}{*}{ Elevation $(\mathrm{m})$} & \multirow[t]{5}{*}{0.056} & $181-228$ & 37.71 & 0.06 & 1 \\
\hline & & $228-268$ & 35.43 & 0.13 & 2 \\
\hline & & $268-326$ & 17.10 & 0.19 & 3 \\
\hline & & $326-401$ & 9.05 & 0.25 & 4 \\
\hline & & $401-645$ & 6.70 & 0.38 & 6 \\
\hline \multirow[t]{3}{*}{ Drainage density $\left(\mathrm{km} / \mathrm{km}^{2}\right)$} & \multirow[t]{3}{*}{0.056} & $0.042-0.466$ & 12.08 & 0.18 & 3 \\
\hline & & $0.466-0.889$ & 31.30 & 0.19 & 4 \\
\hline & & 0.889-1.313 & 29.85 & 0.20 & 5 \\
\hline
\end{tabular}

Page 13/19 


\begin{tabular}{|llllll|} 
& $1.313-1.736$ & 19.90 & 0.21 & 6 \\
\cline { 2 - 6 } & & $1.736-2.160$ & 6.85 & 0.22 & 7 \\
& 0.037 & $6.32-9.32$ & 26.23 & 0.09 & 1 \\
\cline { 2 - 6 } & $9.32-11.76$ & 58.94 & 0.19 & 2 \\
\hline
\end{tabular}

Table 4 Area of gully erosion susceptibility zone

\begin{tabular}{|lll|}
\hline Gully erosion susceptibility zone & Area $\left(\mathrm{km}^{2}\right)$ & Area (\%) \\
\hline Very low & 28.09 & 19.72 \\
\hline Low & 40.60 & 28.49 \\
\hline Moderate & 33.08 & 23.22 \\
\hline High & 28.34 & 19.88 \\
\hline Very high & 12.37 & 8.68 \\
\hline
\end{tabular}

Table 5 Accuracy level of the study

\begin{tabular}{|llll|}
\hline Gully erosion susceptibility zone & Number of sites & Total sites & Level of accuracy $(\%)$ \\
\hline Very low & 1 & 11 & 72.72 \\
\hline Low & 2 & & \\
\cline { 1 - 2 } Moderate & 2 & & \\
\cline { 1 - 2 } High & 3 & & \\
\cline { 1 - 2 } Very high & 3 & & \\
\hline
\end{tabular}

\section{Figures}

Figure 1

Location of the study area 


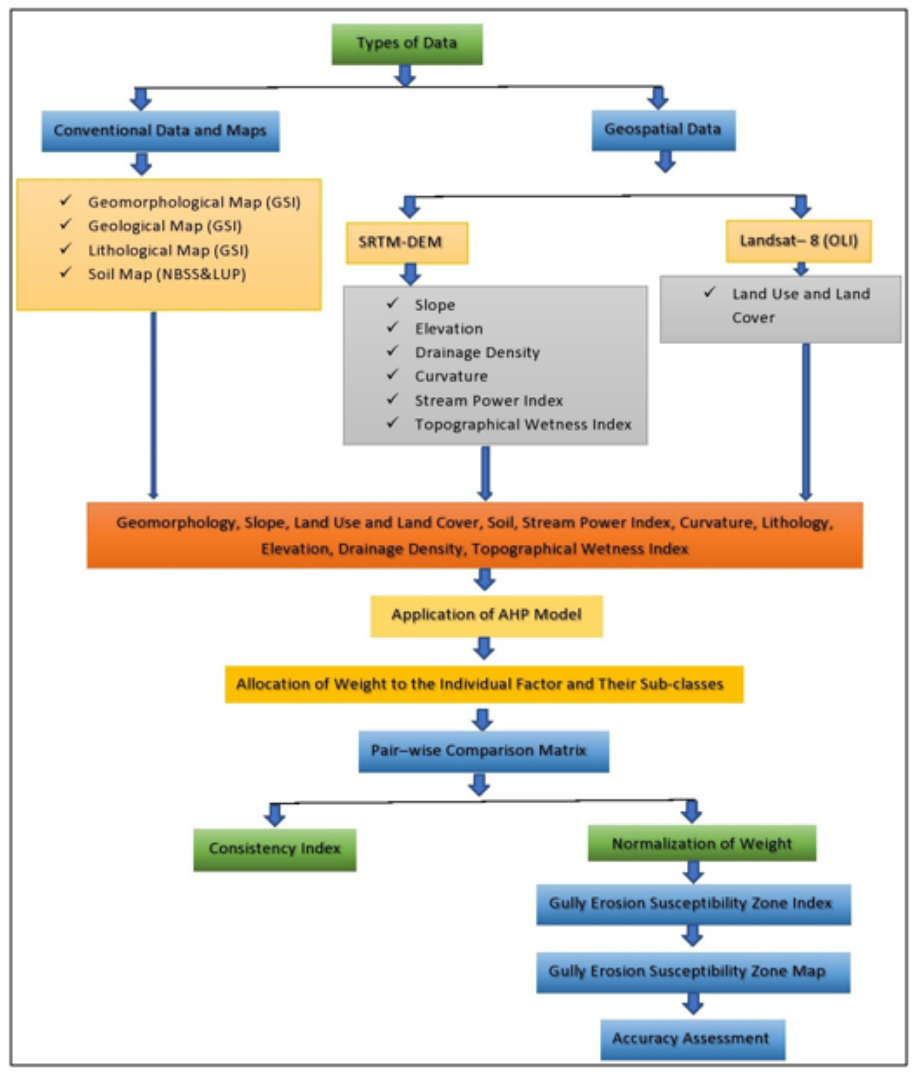

Figure 2

Showing details of methodology

\begin{tabular}{|c|c|c|c|c|c|c|}
\hline $85^{\circ} 53^{\prime} 40^{\prime \prime E}$ & $85^{\circ} 55^{\prime} 30^{\prime \prime E}$ & $85^{\circ} 57^{\prime} 20^{\prime \prime} \mathrm{E}$ & $85^{\circ} 59^{\prime} 10^{\prime \prime} \mathrm{E}$ & $86^{\circ} 1^{\prime} 0^{\prime \prime E}$ & $86^{\circ} 2^{\prime} 50^{\prime \prime} \mathrm{E}$ & $86^{\circ} 4^{\prime} 40^{\prime \prime} \mathrm{E}$ \\
\hline
\end{tabular}

\section{Figure 3}

Geomorphology map of Rupai river basin 


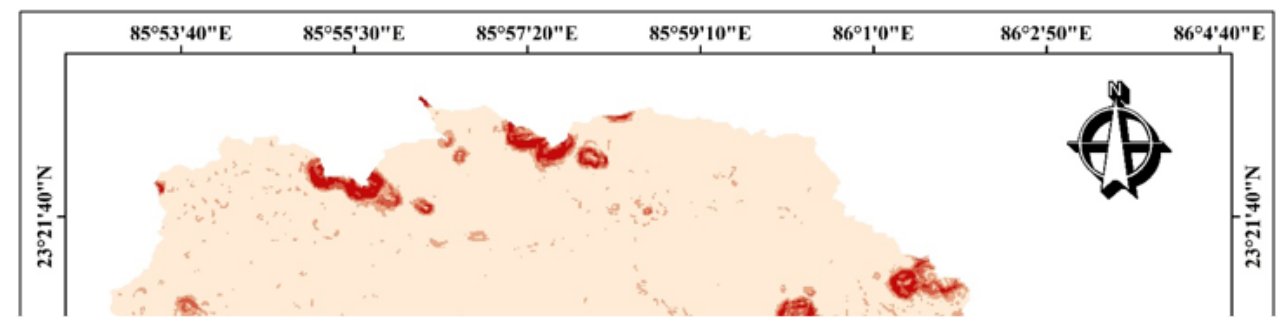

Figure 4

Slope map of Rupai river basin

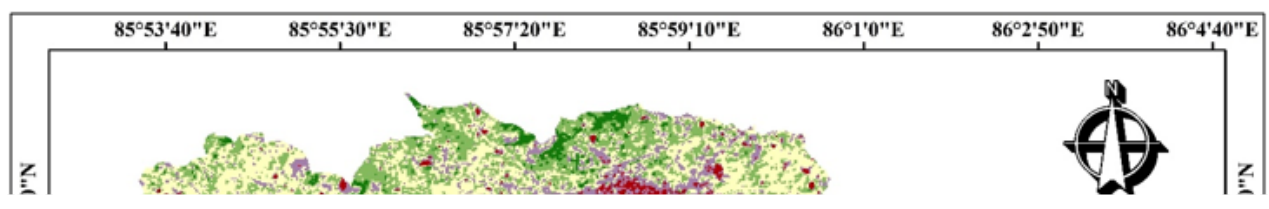

Figure 5

Land use land cover (LULC) map of Rupai river basin

Figure 6

Soil map of Rupai river basin 


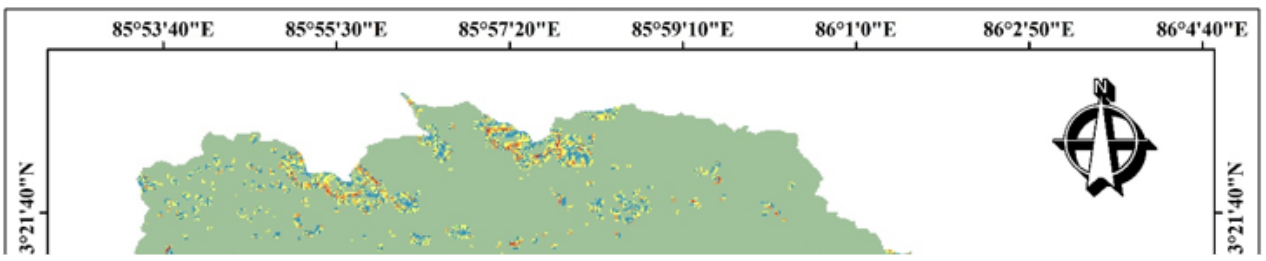

Figure 7

Stream power index (SPI) map of Rupai river basin

\section{Figure 8}

Curvature map of Rupai river basin

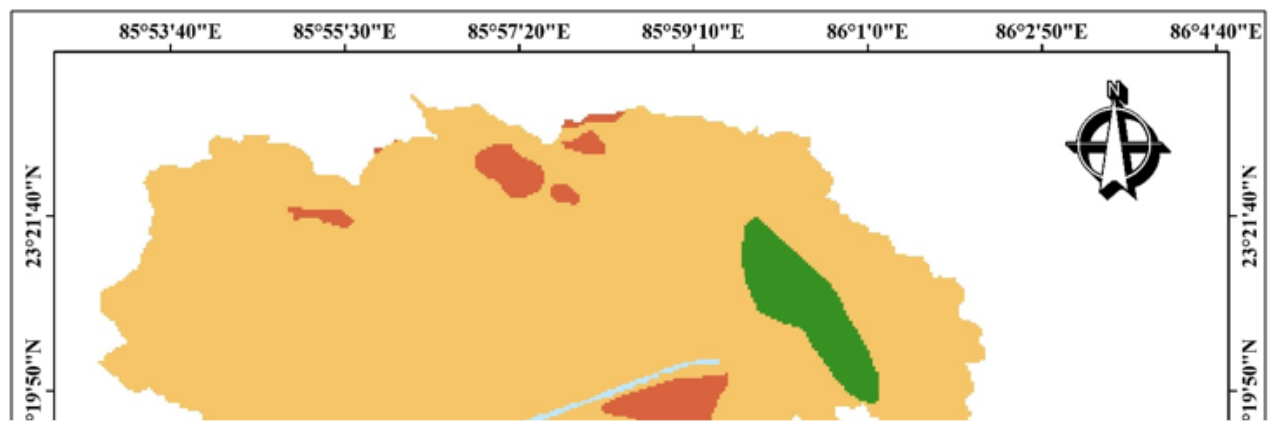

Figure 9

Lithology map of Rupai river basin

Figure 10

Page 17/19 
Figure 11

Drainage density map of Rupai river basin

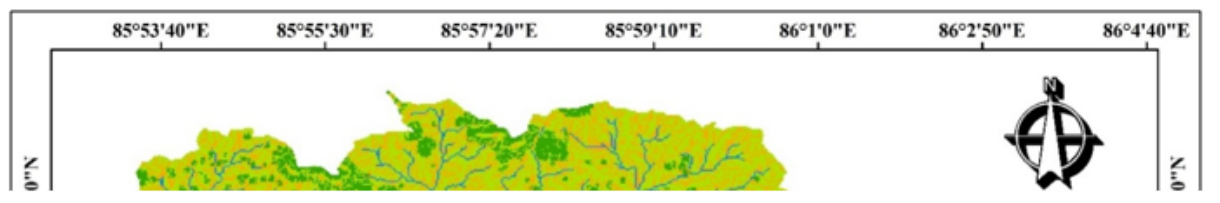

\section{Figure 12}

Topographical wetness index (TWI) map of Rupai river basin

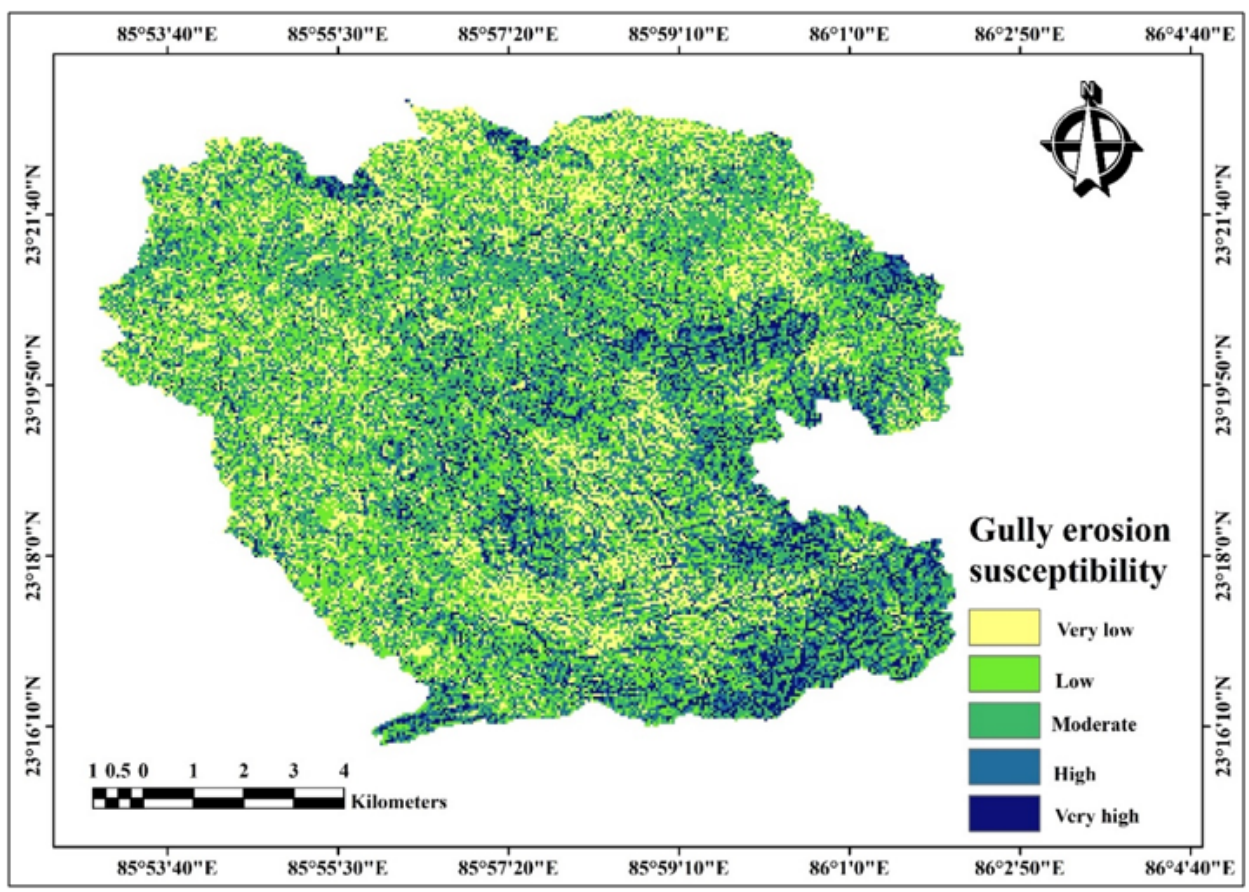

\section{Figure 13}

Gully erosion susceptibility zones map of Rupai river basin 


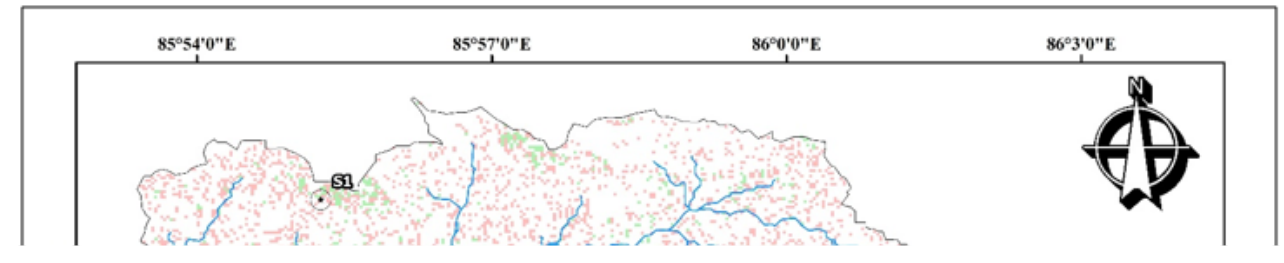

Figure 14

GPS location map of gully in field with HSZ and VHSZ in Rupai river basin

\section{Supplementary Files}

This is a list of supplementary files associated with this preprint. Click to download.

- plate1.png 